\title{
SAMUEL KUCHEROV
}

\section{Reply}

My article was based on research undertaken for a book-length study of the history of prerevolutionary Russian law (862-1917) which I am preparing. It could not, of course, discuss exhaustively all the topics it mentions.

Professor Backus's comments call for answer on four points. First, that the Russkaia Pravda was the "law in action" in its time is not questioned by any of the numerous tsarist, Soviet, or foreign experts. Any doubt is excluded by the fact that the Russkaia Pravda was reproduced in many sources as the law in force at the time. Professor Backus in fact comes to the same conclusion by a very interesting contraposition of the various parts of the Russkaia Pravda which is complicated and seems to me superfluous. The controversy about whether the Pravda was an official code promulgated by the highest state authority or a private collection of laws does not affect the fact that it was the "law in action." Second, the influence of Scandinavian law on the Russkaia Pravda is denied by the overwhelming majority of scholars. The main reason is that the legislation that could be compared with the Pravda is of later provenance. That some Scandinavian customs imported by the Varangians could have influenced the Pravda is certainly possible but very difficult to establish, and the problem could not have been solved within the framework of my article. Third, a custom becomes customary law not merely when its violation is punishable but also when its consequences are recognized and protected by law. For example, the children of a commonlaw marriage in old Russia had the same status as those from a religious marriage, and in the Soviet Union until 1944 the same status as those of a marriage performed by Zaks; the right of alimony was also the same. Certainly going to the bania is a simple custom and not a customary law. Fourth, I am thankful to Professor Backus for his suggestions for modifying my mode of analysis and so forth, but I am not persuaded of the necessity of following them.

I am grateful to Professor Hammer for his discussion of the Russkaia Pravda. However, since on the few occasions when he mentions my article he shares my opinion, no reply is needed. 